ARTICLE

Check for updates

https://doi.org/10.1057/s41599-020-0469-5

\title{
Postdoctoral scholars' perspectives about professional learning and development: a concurrent mixed-methods study
}

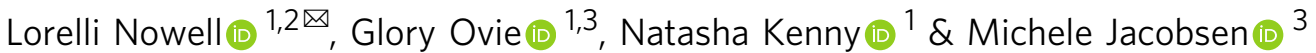

\begin{abstract}
Postdoctoral scholars pursue diverse career paths requiring broad skill sets; however, little is known about postdoctoral scholars' perspectives about their professional learning, and development needs. The objective of this mixed-methods study was to identify current professional learning and development opportunities used by postdoctoral scholars to obtain the required broad skills sets of value for a changing career landscape. A concurrent mixed-methods design was utilized including a cross sectional survey and qualitative interviews. Analysis was conducted using descriptive statistics and thematic analysis; quantitative and qualitative findings were then triangulated for convergent themes. Key findings indicate that although postdoctoral scholars engage in a variety of professional learning, the perceived usefulness of these sessions varies widely, and the types of professional learning and development that they engage in, may not best support the realities of their future careers. Given the significant resources often required to support professional learning and development initiatives, a deeper understanding and alignment of postdoctoral scholars needs with provided opportunities may help to ensure scarce resources are invested in the most useful and effective strategies.
\end{abstract}

\footnotetext{
${ }^{1}$ Taylor Institute for Teaching and Learning, University of Calgary, 434 Collegiate Boulevard NW, Calgary, AB T2N 1N4, Canada. ${ }^{2}$ Faculty of Nursing, University of Calgary, Calgary, AB T2N 1N4, Canada. ${ }^{3}$ Werklund School of Education, University of Calgary, Calgary, AB T2N 1N4, Canada.

凶email: Inowell@ucalgary.ca
} 


\section{Introduction}

ostdoctoral scholars (postdocs) are traditionally employed in short-term mentored research positions (1-5 years) during which time they are expected to make significant contributions to research productivity (Clotfelter, 2010). Although these fellowships are intended to bridge the gap between Ph.D completion and tenure track faculty positions (Jadavji et al., 2016), the number of postdocs far exceeds the universities' need for new academic faculty (Fuhrmann et al., 2011; Jadavji et al., 2016; McKenzie, 2007). With fewer than $20 \%$ of postdoctoral scholars moving into tenure-track positions (Edge and Munro, 2015), postdocs are being forced to follow diverse research career paths or leave research altogether (Fuhrmann et al., 2011).

As many postdocs pursue careers outside of academia, often within industry, government, and private sectors, there is a growing need to provide opportunities on campus to develop broader skill sets to ensure success in various career streams. Postdocs have voiced the need for more adequate professional learning and development opportunities to prepare them for diverse career roles (Brownell and Tanner, 2012; Nerad and Cerny, 1999; Rybarczyk et al., 2011). While emphasis has been placed largely on research skill development, engaging in a range of professional learning and development activities may increase postdocs' knowledge, skills, abilities, and growth while improving their performance in present or future positions (Åkerlind, 2005; Webster-Wright, 2009).

In a recently published systematic review, the authors determined professional learning and development positively impacted postdocs' teaching and learning skills, writing and publication skills, and general career skills (Nowell et al., 2018). Other outcomes of engaging in professional learning and development included developing a community of peers with other postdocs, enhancing work-life balance, and purposefully planning for professional learning and development (Nowell et al., 2018). The authors conducted a further literature review and identified common goals for professional learning and development initiatives for postdocs were to develop teaching and learning, mentorship, academic writing, networking, and communication skills (Nowell et al., 2020). Although these reviews provide a picture of the professional learning and development approaches, there remains a lack of research that documents postdocs' perceptions of professional development opportunities, the learning gained from engaging in these opportunities, and how knowledge and skills developed through these opportunities is utilized.

\section{Aims}

In order to help address this research gap, the overarching aims of the study were to:

1. Explore postdocs' perceptions of professional development, learning gains from engaging in professional development opportunities, and how postdocs have used the knowledge and skills developed through these opportunities at a large, research-intensive institution.

2. Describe and examine the impact of professional development opportunities for postdocs and identify gaps in current professional development opportunities.

\section{Methods}

Design. A concurrent mixed-methods design (Creswell, 2014) was utilized including: (1) a cross sectional survey of postdoctoral scholars to identify their perspectives about professional learning and development opportunities; and, (2) qualitative interviews with self-selected postdoctoral scholars to explore perspectives and involvement with professional learning and development. Results were triangulated to develop a robust and meaningful picture of professional learning and development for postdocs.

Setting and context. Our large Canadian research university attracts national and international postdocs who have developed advanced research skills and perspectives at other leading institutions. These scholars have a significant impact on promoting discovery, creativity, and innovation through their groundbreaking research. Currently, our university employs $\sim 500$ postdocs from various disciplinary backgrounds who have access to world-class research leaders, as well as diverse professional learning and development opportunities.

Ethical considerations. Permission to conduct this research was granted through the local Research Ethics Board (REB17-1795). Informed consent was included as the first page of the survey and consent was implied through survey completion. Interview participants provided written and verbal consent prior to data collection. Participants were made aware that only aggregated data would be presented during dissemination.

Sample/participants. Voluntary participation was sought from $\sim 500$ multidisciplinary postdocs currently employed at a large research focused Canadian University.

\section{Data collection}

Survey. Following well-established methods (Rattray and Jones, 2007), a survey was developed based on results of a document analysis and rigorous review of the literature (Nowell et al., 2018). The survey included demographic items, questions about professional development, perceptions of professional development opportunities, learning gained through engaging in these opportunities, and how knowledge and skills developed through these opportunities was utilized. Participants were also invited to provide written comments about additional professional learning and development opportunities they engaged in or wished to engage in. At the end of the survey, participants were asked to indicate their willingness to participate in a follow up interview. The survey took $\sim 5-10 \mathrm{~min}$ to complete, and all survey data were collected between October 2018 and January 2019 using an electronic survey, supported by Qualtrics software.

Interviews. The semi-structured interview guide consisted of open-ended questions designed to explore each participant's perspectives and involvement with professional learning and development opportunities. Individual face-to face interviews lasting between 15 and 20 min were digitally recorded and transcribed verbatim. Interview questions included:

- Can you describe your experiences with professional learning and development as a postdoctoral scholar?

- How have you sought out professional learning and development opportunities?

- What opportunities have best supported your personal, professional, and academic learning and development and why?

- How have you used the knowledge and skills developed through professional learning and development opportunities?

- How does the professional learning and development you receive from your supervisor differ from the professional learning and development you engage in independently? 
Data collection continued until all participants who indicated their desire to participate had completed an interview and data saturation was achieved (Miles et al., 2014).

\section{Data analysis}

Survey. Survey data were exported from Qualtrics into excel, cleaned, and then imported into SPSS (version 22) statistical software package. Descriptive statistics included frequencies and percentages. Kruskal-Wallis tests were conducted to examine differences between participants. Written responses to openended questions were coded and thematically analyzed (Pallant, 2013).

Interviews. The process of qualitative data collection and analysis occurred iteratively (Creswell, 2014). Transcripts were assigned unique identifiers and imported into NVivo (version 12) to support the organization and coding of the data. A six-step thematic analysis guided an iterative and reflective process involving a constant moving back and forward between each of the six steps (Nowell et al., 2017).

Integration. We used an integrated data display to visually present both qualitative and quantitative data (Lee and Green, 2007; Onwuegbuzie and Dickinson, 2008). By incorporating multiple variables into a table, we were able to analyze the relationship among variables, based on the visual patterns of the data. These multiple pieces of evidence provide documentation of our dataset, and a visual summary of narrative content.

\section{Validity, reliability, and rigour}

Survey. To determine the face validity of the survey, preliminary review was sought from postdoctoral scholars from various disciplinary backgrounds. Reviewers were asked if the directions and statements were clear, adequately reflected the literature, and if any items needed to be revised or deleted. The revised survey was sent back to these reviewers to ensure concerns were adequately addressed. Content validity was not used as the survey was constructed based on all available literature about professional learning and development of postdoctoral scholars.

Interviews. Data collection, integration, and prolonged engagement with the data were used to increase the probability of credible findings being produced (Lincoln and Guba, 1985). To achieve dependability, we ensured our research process was logical, traceable, and clearly documented by creating an audit trail (Koch, 1994; Tobin and Begley, 2004). All records of raw data were kept to systemize, relate, and cross reference data, as well as ease the reporting of the research process (Halpren, 1983). The authors met frequently to establish authenticity and trustworthiness of the research, and to ensure interpretations were clear to the readers and true to the data.

\section{Results}

Participant characteristics. There were 100 respondents and 76 completed surveys for an approximate response rate of $20 \%$ and a completion rate of $76 \%$. A total of $65 \%$ of postdocs who completed the survey were between 25 and 34 years old, $42 \%$ from medicine, and the majority were international (57\%). In total, 23 survey participants provided their email addresses to indicate their willingness to participate in interviews, and 18 participated in a semi-structured interview. A larger proportion of those who volunteered to participate in an interview identified as a female and Canadian citizens. The characteristics for survey and interview participants are displayed in Table 1.
Table 1 Characteristics of participants for surveys and interviews.

\begin{tabular}{|c|c|c|c|c|}
\hline \multirow[t]{2}{*}{ Characteristics } & \multicolumn{2}{|c|}{$\begin{array}{l}\text { Surveys } \\
(n=94)\end{array}$} & \multicolumn{2}{|c|}{$\begin{array}{l}\text { Interviews } \\
(n=18)\end{array}$} \\
\hline & $n$ & $\%$ & $n$ & $\%$ \\
\hline \multicolumn{5}{|l|}{ Gender } \\
\hline Male & 30 & 31.9 & 5 & 27.8 \\
\hline Female & 64 & 68.1 & 13 & 72.2 \\
\hline \multicolumn{5}{|l|}{ Age } \\
\hline Less than 25 years & 0 & 0 & 0 & 0 \\
\hline $25-34$ years & 60 & 65.2 & 10 & 55.5 \\
\hline $35-44$ years & 28 & 30.4 & 7 & 39 \\
\hline $45-54$ years & 3 & 3.3 & 1 & 5.5 \\
\hline 55 years plus & 1 & 1.1 & 0 & 0 \\
\hline \multicolumn{5}{|l|}{ Faculty } \\
\hline Arts & 8 & 8.7 & 0 & 0 \\
\hline Engineering & 14 & 15.2 & 3 & 16.7 \\
\hline Environmental design & 1 & 1.1 & 0 & 0 \\
\hline Business & 1 & 1.1 & 1 & 5.6 \\
\hline Medicine & 39 & 42.4 & 6 & 33.3 \\
\hline Kinesiology & 4 & 4.3 & 1 & 5.5 \\
\hline Nursing & 5 & 5.4 & 2 & 11.1 \\
\hline Science & 16 & 17.4 & 2 & 11.1 \\
\hline Veterinary medicine & 4 & 4.4 & 3 & 16.7 \\
\hline \multicolumn{5}{|l|}{ Year of postdoctoral fellowship } \\
\hline Year 1 & 22 & 23.9 & 4 & 22.3 \\
\hline Year 2 & 35 & 38 & 6 & 33.3 \\
\hline Year 3 & 19 & 20.7 & 2 & 11.1 \\
\hline Year 4 & 9 & 9.8 & 4 & 22.3 \\
\hline Year 5 & 5 & 5.4 & 1 & 5.5 \\
\hline More than 5 years & 0 & 0 & 0 & 0 \\
\hline Completed fellowship & 1 & 2.2 & 1 & 5.5 \\
\hline \multicolumn{5}{|l|}{ Citizenship status } \\
\hline International postdoc with work permit & 39 & 42.4 & 6 & 33.3 \\
\hline Permanent resident/landed immigrant & 14 & 15.2 & 3 & 16.7 \\
\hline Canadian citizen & 39 & 42.4 & 9 & 50 \\
\hline
\end{tabular}

Table 2 Postdoctoral scholars future employment aims.

\begin{tabular}{|c|c|c|c|c|}
\hline \multirow[t]{2}{*}{ Future employment aims } & \multicolumn{2}{|c|}{$\begin{array}{l}\text { Only one } \\
\text { option } \\
\text { selected }\end{array}$} & \multicolumn{2}{|c|}{$\begin{array}{l}\text { Multiple } \\
\text { options } \\
\text { selected }\end{array}$} \\
\hline & $n$ & $\%$ & $n$ & $\%$ \\
\hline Government & 1 & 1.0 & 26 & 27.6 \\
\hline Corporate/industry & 7 & 7.4 & 33 & 35.1 \\
\hline Not-for-profit & 0 & 0 & 4 & 4.3 \\
\hline Self employed & 0 & 0 & 4 & 4.3 \\
\hline Postsecondary education & 44 & 46.8 & 77 & 81.9 \\
\hline Other & 2 & 2.1 & 0 & 0 \\
\hline
\end{tabular}

Survey participants were asked to indicate their future employment aims. Some postdocs selected only one option while others selected multiple options. The results are displayed in Table 2. A total of 44 postdocs $(46.8 \%)$ selected working at a postsecondary institution as their only option and 77 postdocs (81\%) indicated they were aiming for an academic position at a postsecondary institution while also indicating other career options for consideration. Based on Kruskal-Wallis tests, there are no differences between the proportion of postdocs who aim for postsecondary positions compared to those considering other 
options in terms of gender $(p=0.332)$, age group $(p=0.352)$, postdoc year $(p=0.661)$, and citizenship status $(p=0.115)$. Examining the distribution by citizenship status revealed fewer (only 35\%) international postdocs holding a work/study permit aim for an academic career only, compared to Canadian citizens and/or landed immigrants (55\% and $60 \%$, respectively). When the Canadian citizens and landed immigrants are grouped together, the difference between them and the international postdocs $(57 \%$ versus $35 \%)$ is statistically significant, chisquare $=4.268, p=0.039$ and Kruskal-Wallis, $p=0.040$.

Survey results. A high-level summary of survey results is presented alongside interview findings in Table 3. Survey respondents were asked to identify postdoctoral professional learning and development opportunities they attended and rate how useful these opportunities were on a scale of 1-10 (ten being the most useful). The options in the survey were based on a list of workshops provided by our University's postdoc office. Bases on Kruskal-Wallis tests, there were no differences in attendance between genders for the different categories of professional learning and development, except for communication skills. There were more women than men who attended communication skills workshops ( $p=0.034$, Kruskal-Wallis test). Likewise, more women than men attended networking events but the difference was not significant. There were no differences in attendance among the age groups for the different categories of professional learning and development, except for project management, where the majority of $45+$ years old group (75\%) attended the workshop. Respondents who had been in their postdoctoral fellowship for 3 years or more were more likely to have attended or are interested in attending professional learning and development opportunities aimed at building academic writing skills $(p=0.027)$, and communication skills $(p=0.028)$. International postdoctoral scholars and landed immigrants were most likely to attend networking opportunities $(p=0.054)$. Landed immigrants were also likely to have attended or were interested in attending the professional learning and development opportunities focused on building academic writing skills $(p=0.033)$, project management skills $(p=0.049)$, and career planning $(p=0.001)$. On the other hand, more Canadian citizens, when compared to postdocs with other citizenship status's, attended teaching and learning opportunities $(p=0.054)$.

Teaching and learning workshops were rated as the most useful followed by project management and time-management offerings. Those perceived as the least useful professional learning and development opportunities were mentorship workshops and academic writing workshops. Postdocs did not rate any professional learning and development opportunities higher than 7.94 out of 10, indicating many of the options were not deemed to be that useful or were not resonating with those we surveyed.

Respondents were asked to place 12 broad categories of postdoctoral professional learning and development found in the literature in order of importance with one being the most important. The top three rated categories were academic writing, career planning, and academic career skills. The bottom three categories were time management, industry career skills, and networking. Interestingly, the top-rated categories were all more closely related to academic careers while the lowest rated categories were most closely related to careers outside of academia. There were no differences in average rank scores between males and females except for the networking category where women ranked this category significantly of higher importance than men $(p=0.011)$. Because of the relatively small numbers in the lower and higher age groups, we collapsed these categories into only 2 age groups (25-34 years and $35+$ years).
There were no significant differences between age groups in the average rank of importance amongst the different types of professional learning categories, except for communication skills. The $35+$ years age group gave a higher average score than the 25-34 years group (7.80 versus $5.20, p=0.014)$. There were no significant differences between the average rank of importance across the types of professional learning categories and years of postdoctoral fellowship, citizenship status, or future employment aims.

Participants were asked to identify any additional professional learning and development opportunities they attended in open text boxes. These data were organized according to the 12 broader categories of professional learning and development found in the literature (Nowell et al., 2018; Nowell et al., 2020). Generally, these opportunities were associated with postdoctoral fellowships, including writing grants, mentoring junior student in research labs, and attending conferences.

Respondents were also asked to list any additional professional learning and development opportunities they would like to see offered to postdoctoral scholars in an open text box. These data were similarly organized according to the 12 broader categories of professional learning and development found in the literature. Remarkably, postdocs mentioned a desire to engage in opportunities related to industry and government careers alongside more traditional academic development opportunities.

\section{Interview findings}

Perceptions of professional learning and development opportunities. Participants agreed there were many professional learning and development opportunities available for postdocs with some stating they "feel really well supported regarding professional development." (P5), and others stating they are "surprised about the large variety of things that are available here for post docs" (P3). Although it was clear there are a number of professional learning and development opportunities, these often conflicted with postdocs' priority of conducting research, as indicated by the following statement, "I haven't participated in a lot. I've sort of heard of them and seen them come through, but primarily my goal as a post-doctoral researcher was to get published and do research" (P15). Although postdocs were aware of the professional learning and development opportunities, there was a sense they conflicted with other postdoc priorities, with comments such as, "It looks like there's some good opportunities, I just don't know if I can commit to them" (P18), and "I feel like in that department they don't really encourage too much exploration. They're only just research focused." (P17). However, those who engaged in professional learning and development saw this as valuable in terms of, "improving myself as a post doc, so as a researcher, as a mentor and as a teacher" (P16). As postdocs neared the end of their postdoc tenure, many professional learning and development opportunities became more relevant.

You know what, for a long time, I didn't realize after I got my Ph.D degree, I still needed to learn some professional skills. Until early this year... I realized I still need to learn some professional skills. It's fair to say, I don't have too much experience in that area. But, we need to learn. (P4)

As I started thinking about next steps, became aware of what I know and what I'm not sure of in terms of professional learning and development and what's available. A little bit so I would say my experiences are a kind of minimal, but working on gaining more experiences. (P16)

Seeking out professional learning and development opportunities. Many postdocs actively sought out specific professional learning 
Table 3 Summary of survey results and interview findings.

\begin{tabular}{|c|c|c|c|c|c|c|}
\hline & \multicolumn{5}{|c|}{ Survey results } & \multirow{3}{*}{$\begin{array}{l}\text { Interview findings } \\
\text { Exemplar quotes }\end{array}$} \\
\hline & \multicolumn{2}{|c|}{$\begin{array}{l}\text { Usefulness } \\
\text { of } \\
\text { opportunities }\end{array}$} & \multirow{2}{*}{$\begin{array}{l}\text { Rating of } \\
\text { importance } \\
\text { rank order } \\
(1-12)\end{array}$} & \multirow[t]{2}{*}{$\begin{array}{l}\text { Additional } \\
\text { opportunities } \\
\text { attended }\end{array}$} & \multirow[t]{2}{*}{$\begin{array}{l}\text { Additional } \\
\text { opportunities wanted }\end{array}$} & \\
\hline & $n$ & $\begin{array}{l}\text { Mean } \\
\text { Median } \\
\text { Range } \\
(1-10) \\
\end{array}$ & & & & \\
\hline $\begin{array}{l}\text { Teaching and } \\
\text { learning }\end{array}$ & 33 & $\begin{array}{l}7.94 \\
8 \\
(4-10)\end{array}$ & 5 & $\begin{array}{l}\text { - Teaching lectures } \\
\text { in home discipline } \\
\text { - Developing } \\
\text { teaching philosophy } \\
\text { - Developing } \\
\text { teaching dossier }\end{array}$ & $\begin{array}{l}\text { Teaching undergraduate } \\
\text { courses } \\
\text { - Opportunities to give guest } \\
\text { lectures }\end{array}$ & $\begin{array}{l}\text { "I do want a career that is both research and teaching... I've also } \\
\text { been looking for teaching opportunities to develop my abilities, my } \\
\text { skills in teaching. Those have also been difficult to come by } \\
\text { unfortunately." (P17) }\end{array}$ \\
\hline Mentorship & 2 & $\begin{array}{l}5.0 \\
5 \\
(5-5)\end{array}$ & 6 & $\begin{array}{l}\text { Workshops on } \\
\text { mentoring and } \\
\text { supervising } \\
\text { students } \\
\text { - Mentoring } \\
\text { graduate students } \\
\text { and junior level } \\
\text { postdocs } \\
\text { - External } \\
\text { mentorship } \\
\text { program }\end{array}$ & $\begin{array}{l}\text { Mentoring and managing } \\
\text { small groups } \\
\text { - Workshops on developing } \\
\text { mentorship skills } \\
\text { - Mentorship from } \\
\text { communities of practice }\end{array}$ & $\begin{array}{l}\text { "I've had an opportunity to mentor a lot of students one-on-one ... } \\
\text { I think that I get the most benefit from that professionally, } \\
\text { because it's sort of reinforcing what I know by teaching, and it's } \\
\text { more related to my professional career." (P15) }\end{array}$ \\
\hline Industry career skills & & & 11 & & $\begin{array}{l}\text { Internships in government } \\
\text { and private sectors } \\
\text { - Industry networking } \\
\text { opportunities } \\
\text { - Workshop on transitioning } \\
\text { from postdoc to industry }\end{array}$ & \\
\hline Academic writing & 10 & $\begin{array}{l}5.05 \\
5 \\
(1-10)\end{array}$ & 1 & $\begin{array}{l}\text { Writing grants } \\
\text { - Reviewing grants } \\
\text { - Grant writing } \\
\text { workshop }\end{array}$ & $\begin{array}{l}\text { Grant writing for social } \\
\text { sciences } \\
\text { - Budget preparation }\end{array}$ & $\begin{array}{l}\text { "I found those writing workshops helpful for post-doc funding } \\
\text { applications... It seems like we're always applying for funding and } \\
\text { I used a lot of the skills presented at the grant writing workshop in } \\
\text { my actual post-doc funding application." (P5) }\end{array}$ \\
\hline Career planning & 3 & $\begin{array}{l}6.67 \\
6 \\
(5-9)\end{array}$ & 2 & $\begin{array}{l}\text { Job fair for } \\
\text { post docs } \\
\text { - Job application } \\
\text { workshops }\end{array}$ & $\begin{array}{l}\text { Career workshops } \\
\text { - Career coaching } \\
\text { - Career/job fair for } \\
\text { employers looking to hire } \\
\text { postdocs }\end{array}$ & $\begin{array}{l}\text { "The university is of no help for those wanting to pursue jobs in } \\
\text { academia. Instead post-docs are left to garner advice from their } \\
\text { mentors/supervisors... the quality of supervision varies by mentor } \\
\text { and so will the quality of help and advice... it very hard for some } \\
\text { people to view their supervisors as people they can turn to for } \\
\text { advice and feedback." }\end{array}$ \\
\hline Networking & 61 & $\begin{array}{l}6.53 \\
7 \\
(1-10)\end{array}$ & 10 & $\begin{array}{l}\text { Networking with } \\
\text { other postdocs }\end{array}$ & $\begin{array}{l}\text { Collaborative resource to } \\
\text { identify potential } \\
\text { collaborators for research } \\
\text { and expertize }\end{array}$ & $\begin{array}{l}\text { "At the conferences I have opportunity to network with people } \\
\text { that are doing research that is similar to mine and I can build } \\
\text { some collaboration. It's not the same in send an email, it's actually } \\
\text { a face to face opportunity. You can also have a feeling if you trust } \\
\text { this person as a collaborator". (P2) }\end{array}$ \\
\hline $\begin{array}{l}\text { Academic } \\
\text { career skills }\end{array}$ & & & 3 & $\begin{array}{l}\text { Weekly lectures } \\
\text { given by field- } \\
\text { specific experts } \\
\text { - Grants } \\
\text { adjudication } \\
\text { - Awards } \\
\text { adjudication }\end{array}$ & $\begin{array}{l}\text { Garnering postdoc } \\
\text { research grants } \\
\text { - Mock interviews for } \\
\text { academic positions } \\
\text { - Writing research } \\
\text { statements and } \\
\text { research plans } \\
\text { - Negotiating start up } \\
\text { packages } \\
\text { - Peer reviewing grants }\end{array}$ & $\begin{array}{l}\text { "this is how you apply for a faculty position, job ...those tend to be } \\
\text { more related to exactly what I would like to do } \\
\text { professionally." (P9) }\end{array}$ \\
\hline Communication skills & 23 & $\begin{array}{l}6.09 \\
7 \\
(3-9)\end{array}$ & 7 & $\begin{array}{l}\text { Attending } \\
\text { conferences } \\
\text { - Research } \\
\text { presentations } \\
\text { - Interactions with } \\
\text { other researchers }\end{array}$ & $\begin{array}{l}\text { Preparing/formatting CV } \\
\text { - Interviewing skills } \\
\text { - Communication skills for } \\
\text { English as a second language } \\
\text { - Preparing for a job talk }\end{array}$ & $\begin{array}{l}\text { "Attending seminars and professional conferences has really } \\
\text { helped, so kind of yeah getting a wide variety of experience and } \\
\text { also kind of starting to figure out how to develop those skills with } \\
\text { more I guess structured kind of things like seminars, workshops } \\
\text { and that sort of thing." (P16) }\end{array}$ \\
\hline \multicolumn{7}{|l|}{ Personal effectiveness } \\
\hline Work-life balance & & & 4 & & $\begin{array}{l}\text { How to integrate your } \\
\text { personal values into your } \\
\text { professional work }\end{array}$ & \\
\hline Leadership skills & 16 & $\begin{array}{l}5.83 \\
6 \\
(2-9)\end{array}$ & 8 & $\begin{array}{l}\text { Leadership in the } \\
\text { research lab }\end{array}$ & Diversity awareness & $\begin{array}{l}\text { "leadership type workshops where you learn about,... what } \\
\text { motivates different people, what motivates you, and it was a good } \\
\text { reflective piece, which didn't have a lot to do with academia or } \\
\text { anything like that. So personally that was quite good." (P8) }\end{array}$ \\
\hline $\begin{array}{l}\text { Project } \\
\text { management }\end{array}$ & 9 & $\begin{array}{l}7.11 \\
7 \\
(5-10)\end{array}$ & 9 & & $\begin{array}{l}\text { Project financial } \\
\text { management } \\
\text { - Funding allocation basics }\end{array}$ & \\
\hline Time management & 4 & $\begin{array}{l}7.5 \\
8 \\
(5-9)\end{array}$ & 12 & & & \\
\hline
\end{tabular}

and development opportunities. One participant noted, "most of the time, it's really that I'm looking for it and just doing it" (P1). Postdocs sought out opportunities online and through word of mouth at postdoc events and postdoc peers. Another participant spoke about how they purposefully sought out professional learning and development opportunities that aligned with their future career goals.

Because, I'm very interested in teaching and I'm looking into that as a possible career after I finish with my post doc. 
I have actively sought stuff ... like how to build a teaching portfolio, how to write a teaching philosophy. These, I have actually looked for. (P3)

For other postdoc who were not actively seeking professional learning and development opportunities, they were more likely to actively engage in opportunities that were local, relevant, and serendipitous. Emails sent through a postdocs list serve or email distribution list were viewed as the most efficient and effective way of finding out about professional learning an development opportunities of most interest.

Mostly, they've been sent through email and then just sort of clicked and followed the ones that seem of interest. But they've been really accessible. I haven't really had to hunt about too much because they normally come to us in a weekly email through our Institute. (P5)

Supervisor provided versus independent professional learning and development. The professional learning and development provided by supervisors was viewed differently from opportunities that were sought out elsewhere. Supervisor support was often characterized as most closely related to research development. For example, an interviewee commented that "what I receive from my supervisor, it's more on the practical side. It's more directly within our project, within our research" (P12). Supervisor support was also often perceived as very specific to their field of research, with one participant stating, "coming from the same background, it's different than engaging with people who come from all sorts of disciplinary backgrounds" (P18). To gain a broader skill set and develop a greater understanding of jobs outside of academia, postdocs often looked beyond the support provided by their supervisor as indicated through the below comments:

My supervisor has been very good in training me to be an excellent researcher. So, training me in how to do research and create questions and carry out experiments. Also in scientific writing. It's definitely very important skills for my professional development. On my own I've been trying to seek out all of the other things I need to get a job. Learning how to teach, getting teaching experience and then also if I want to go out of academia, I need a whole other skillset. Depending on what I want to go into. I've also been looking online for online courses, or meeting with people in these other career fields just to get information and get experience. (P17)

So my supervisor, she's a researcher and clinician, and doesn't do any teaching ... so from her I wasn't getting that kind of training, which was fine, which is why I went and pursued more of it through the [teaching and learning workshops]. Her mentorship came from research and writing analysis, discipline-specific research developments, but not teaching and learning. (P8)

So I'd say my supervisor provides an environment to grow that's very specific to my research area and my project, and that involves connecting with other people in the field and recommending conferences that I attend and helping me with the projects that I'm working with. And I think where I have to engage independently is for all the other stuff that's not really so specific to my particular project or field. And that's where other resources... come into play, because they offer other areas of growth and learning and development. (P9)

Likely because many postdoc supervisors have followed a career path in academia, the support they are able, and possibly willing, to provide may be limited to an academic career trajectory.

My supervisor has obviously gone the academic route. He's a professor ... so he knows that kind of route very well and can give me a lot of insight into that. Where that's kind of complicated... is what other kinds of options are also out there, the alternative routes...sometimes the supervisor isn't as useful for those kinds of career paths ... so they're an excellent source of information for the academic route, which lines up for me, but for a lot of people, that's not as useful. (P13)

However, the support provided by supervisors was also seen as being more individualized and tailored to specific goals rather than broad skill development, which was seen as beneficial.

I think that it is a bit more individualistic and tailored to me and my personality and my goals and achievements that I want to accomplish in my career, so I do find that the development that my supervisor provides is very tailored to my strengths and weaknesses and career aspirations whereas while I think out ones I think which benefit me specifically, they are not as tailored as the professional development my supervisor provides. (P6)

my supervisor is very approachable and very open for questions. He sometimes shares things that you're not going to learn from these organized workshops... When I talk to my supervisor, we can go in many directions, and then answer as many different questions... with my supervisor he can pay more attention to me than when we are in a workshop with 40 other people that all have questions. (P3)

Professional learning for professional, academic, and personal development. During the one-on-one interviews, postdocs were asked to identify how professional learning opportunities helped them to develop professionally, academically, and personally; however, participants were often unable to parse their learning into these broad categories. One participant stated, "Yeah, so I looked at the questions and I know you've got it broken out into personal, professional and academic and I feel like they sometimes overlap" (P5). Another noted:

So I think it's very hard for me to make a line out, because to me, professional learning is also developing or giving you personal learning. So, for example, my professional learning in our... if I go to my faculty, that leadership course, that was an important... for my personal life as well, because that gave us some new knowledge about our own personality, weak and strong areas, how to deal with them. And that was, I would say, personal as well as professional learning. Living in a professional environment, it's very hard for me to demarcate. (P14)

During the analysis stages we realized many of the insights provided by the postdocs did not clearly fit into professional, academic, and personal categories, however, the themes began to naturally emerge into the professional learning and development categories found in the literature (Nowell et al., 2018; reference blinded for review). We created a provisional coding template based on our previous reviews of the literature to use on the full dataset to organize segments of similar or related text to assist in the interpretation. The following themes integrate findings from the surveys and interviews with the aim of developing a more rich and insightful understanding of the professional learning and development for postdoctoral scholars. 
Teaching and learning. A total of 33 of 76 postdocs (43\%) indicated they attended some form of professional learning and development related to teaching and learning. Teaching and learning received the highest mean usefulness score of all opportunities attended (7.89 out of 10). Out of the 12 broad professional learning and development categories identified in the literature, teaching and learning was rated as the fifth most important. A number of survey participants indicated a desire to teach in their home discipline and engage in guest lecture opportunities when available. Some participants attended teaching and learning development opportunities because of their strong beliefs about teaching and learning.

I have a deep passion of teaching. And this is based on my own experiences, good or bad, with my teachers, how they used to teach and what I thought could have been changed. So there were some factors which motivated me ...I attended some courses, some workshops on teaching. (P14)

Others engaged in teaching and learning development because it was useful as they began exploring future career opportunities.

I took...the teaching dossier workshop. That one I found very useful, because now that I'm in that transition position and I'm looking for jobs... Also, because I applied for a sessional instruction position they asked for teaching dossier and it's actually something very practical. It's very useful, so I found that, that one was very useful. (P2)

I completed a number of [teaching and learning workshops] for post-doctoral scholars, and professionally those were really excellent because I don't get a lot of teaching and learning development otherwise, and as someone pursuing an academic career, the scholarship teaching and learning issue is a huge part of that. So that was a huge booster for confidence, and applying to interviews it was really helpful. So that was all excellent. (P8)

Some postdocs purposively sought out teaching and learning development opportunities to inform their teaching practice and demonstrate evidence of their teaching knowledge to garner further teaching opportunities during their postdoctoral fellowship.

I've been looking for teaching opportunities.... I've been [taking teaching and learning] workshops, I feel like I have a much better idea of... how to teach, and I've been able to put together an actual teaching dossier. Now that I've been asking people for teaching opportunities, I've been a lot more successful because I can actually send them evidence that I know how to teach. So, I had to have some lectures coming up in the beginning of next year, and I think that's been possible because I have this dossier that I've been able to develop from coming here. That's how I used it for sure. (P17)

Mentorship. Only two postdoctoral scholars indicated they attended formal professional learning and development focused on mentorship and rated the usefulness of this opportunity at 5 out of 10. Mentorship development was rated as the 6th most important out of the 12 broad professional learning and development categories identified in the literature. Survey participants also indicated they gained mentorship experience through mentoring graduate students and junior level postdocs, as well as external mentorship programs. Survey participants further indicated a desire for more opportunities to mentor and manage small research groups, attend workshops on developing mentorship skills, and engage in communities for practice with a mentorship focus. Those who had occasions to mentor others valued these opportunities and viewed them as teaching and learning opportunities for themselves and the students they mentored.

I think mentoring, having the opportunity to mentor students in the lab and do any kind of teaching, and those kinds of experiences during my Ph.D and post doc have really helped me figure out kind of what kind of learner I am and how I want to teach and how I want to influence others' learning. (P16)

so I've had an opportunity to mentor a lot of students oneon-one and things, and I think that I get the most benefit from that professionally, because it's sort of reinforcing what I know by teaching. (P15)

I'm ... with a wonderful supervisor ... he urges us to be involved in the mentorship of the younger ones like the grad students. Under grads. These are probably the best opportunities. (P3)

I think every time I mentor a student, I learn something, and then I can take that when I have a new student to make it better. I think I learned many things about myself and how to mentor a student to get the best out of, for themselves and for myself as well. (P12)

Industry career skills. Industry career skills were rated as the 11th most important out of the 12 broad professional learning and development categories identified in the literature. None of the participants indicated they engaged in formal or informal professional learning and development opportunities focused of the development of industry skills. However, survey participants expressed interest in the open text box responses in engaging in internships in government and private sectors, industry networking opportunities, as well as workshops on transitioning from postdoc to industry careers.

Academic writing. In the survey results, academic writing was rated as the most important out of the 12 broad professional learning and development categories identified in the literature. Ten participants engaged informal professional learning and development opportunities related to academic writing and rated them at 5.05 out of 10 in terms of usefulness. Participants engaged in writing grants, reviewing grants, and attended workshops on grant writing to build their academic writing skills.

Yeah, so professionally grant writing opportunities have been really helpful. I guess I kind of consider it academic as well, but I went to a full day grant writing seminar...and found those super helpful because all of the speakers provided actual examples of what to do and what not to do. (P5)

There was a desire for more focused workshops on grant writing for social sciences awards and budgeting. A participant who attended a grant writing workshop spoke about they were able to use the skills developed through the workshop.

I got to put the grant writing workshop skills into effect when I actually wrote a grant and it was successful. We just 
found out recently so that was really great and the other thing I found those writing workshops helpful for were post-doc funding applications. So I just submitted another round of funding. It seems like we're always applying for funding and I used a lot of the skills and those skills presented at the grant writing workshop in my actual postdoc funding application as well. (P5)

Career planning. Although career planning was ranked as the second most important skill out of the 12 broad professional learning and development categories identified in the literature, only three participants attended professional learning and development opportunities specifically focused on career planning and rated this opportunity at 6.67 out of 10 in terms of usefulness. Some participants indicated they attended a job fair and job application workshops as part of their professional learning and development. Survey participants indicated they are interested in engaging in career coaching, as well as a career fair for employers specifically looking to hire postdocs.

Networking skills. Formal networking opportunities were the most attended of all professional learning and development opportunities with 61 postdocs indicating they engaged in some networking workshops. Respondents rated these initiatives at 6.53 out of 10 in terms of usefulness with ten being the most useful. However, networking was ranked as the tenth most important skill out of the 12 broad professional learning and development categories identified in the literature. Participants appreciated opportunities to network with other postdocs and indicated a collaborative resource to identify potential collaborators for research and expertize would help to build networking capacity and skills. Many participants indicated they enthusiastically sought networking opportunities through comments such as, "I tried to actively seek networking opportunities beyond my group" (P6). The most common venues for networking were conferences that presented opportunities for learning, networking, and building communication skills.

I think also connecting with... people who are doing jobs that I might be interested in. To talk with them and get information that way... attending conferences, presenting at conferences has helped me develop skills in talking with people in the lab environment and colleagues. (P17)

One participant noted how they leveraged networking occasions to inform future research opportunities.

take home message is... "Network." ... I've kind of taken that to heart as well, and if I do go to these conferences ... I try and contact as many people as possible and get to know people, try and keep track of their contact info as well so in the future I can potentially use that information ... And a lot of those could be networking opportunities maintained through LinkedIn or even Twitter. (P13)

Academic career skills. Academic career skills were ranked the third most important skill of the 12 broad professional learning and development categories. Although no formal professional learning and development opportunities were specifically geared towards academic careers skills, postdocs indicated weekly lectures given by field-specific experts, as well as grant and award adjudication opportunities were beneficial in developing academic career skills. Postdocs indicated they would like to engage in mock interviews for academic positions, and attend workshops on writing research statements and research plans, as well as negotiating start up packages in academic positions.

Communication skills. A total of 23 postdocs indicated they attended some form of professional learning and development related to building communication skills and rated the mean usefulness of these opportunities at 6.09 out of 10 (median $=7$, range $=3-9$ ). Out of the 12 broad professional learning and development categories identified in the literature, communication skills were rated as the seventh most important. Some postdocs recognized public speaking was a skill they want to build and they sought out opportunities to push them outside of their comfort zone.

Personal, I think... probably lecturing a little bit. I'm normally pretty shy and don't like giving lectures to a whole group of people, so I've been sort of, that's one thing I do, not always teaching but if it's like a seminar or whatever, kind of try to sign up for it so that I have to do it to try and get over it. So, sort of it's a personal thing that I need to improve. (P15)

For many postdocs, English was an additional language. The opportunity to practice speaking English was a valuable experience for growth and development.

I found that my English was very improved and I thought that it is necessary when you are in communication with your colleagues and so on. When I just arrived ...I hardly could speak English. I could write, but not speak. And now I found that personally I improved in this area. (P1)

Personal effectiveness. Personal effectiveness encompassed a number of topics, including leadership, time management, project management, and work-life balance. Leadership skills were ranked eighth out of 12 in term of importance and 16 postdocs attended leadership development workshops an rated them as 5.83 out of 10 in terms of usefulness. Some postdocs were able to develop leadership skills through their research roles in the lab.

I am more of a leader in the group, and now I'm also gaining contact with the companies and bringing more projects into the university. So that's a whole new experience, because before, as a student, you just wait for your supervisor to get them. And this year, I've been going to a lot of meetings and presenting what we can do and looking the other way, like how much time do they take to decide and how much do you have to bring to the table for them to be able to collaborate with us and all that, so it's been interesting. (P11)

Time management was ranked as the least important out the 12 broad categories identified in the literature. Only four postdocs attended a formal opportunity specifically focused on developing time-management skills and rated this as 7.5 out of 10 in terms of usefulness. No postdocs mentioned additional time-management opportunities attended or desired and time management was not mentioned in any of the interviews.

Nine postdocs attended project management workshops and rated these at 7.11 out of 10 in terms of usefulness. Project management was ranked as ninth most important out of 12 broad categories. There was an expressed desire for professional learning and development opportunities specifically focused on financial management and funding allocation related to research 
projects. Project management was also seen as a transferable skill that could be used across career trajectories.

When I see something like project management, for example, that could be useful for whatever I decide to do after, so whether that's from doing things in a lab in a full academic career, or if it's for consulting or whatever it might be. Even from just like managing family, project management skills are important. I can see that being important. (P7)

Although work-life balance was ranked fourth in terms of importance, there were no specific formal or informal professional learning and development opportunities specifically focused on skills to achieve work-life balance. Some postdocs mentioned a desire to learn more about how to integrate their personal values, including compassion, community, and happiness, to their professional work.

\section{Discussion}

The overarching aim of this study was to explore postdocs' perceptions of professional learning and development opportunities and identify strengths and gaps in current offerings. Our findings suggest that most postdocs are targeting an academic career and choose to focus on professional learning and development most relevant to this career path. However, with fewer than $20 \%$ of postdocs moving into permanent academic positions (Edge and Munro, 2015; Fuhrmann et al., 2011; McKenzie, 2007), there is a clear necessity for postdocs to understand the limited nature of academic aspirations and prepare for diverse careers, roles and responsibilities outside of academic settings (Brownell and Tanner, 2012; Nerad and Cerny, 1999; Rybarczyk et al., 2011). As identified in our findings, the goals for professional learning and development initiatives for postdocs primarily focused on research, even to the exclusion of teaching, which is all oriented towards academia. There is a clear tension between what a postdoctoral fellowship is perceived to be, which is a short-term research position in academia, and the reality that many will not find academic jobs. Higher education institutions that hire postdocs are encouraged to provide professional learning and development opportunities that go beyond careers in academia to meet their diverse needs of postdocs and to invest resources in opportunities that have the highest impact.

Despite the study participants varied engagement in structured professional learning, our interview findings also point to the importance of quality supervision and mentorship in promoting postdoc professional learning and development. Postdocs reflections in the interviews clearly indicated that professional development support from their immediate supervisor was most often oriented to their role as researchers. There is a clear need for postdoc supervisors to provide quality mentorship and support related to the broader skill set aligned with the expanding career trajectory of postdocs, whether that be in academic, industry, public or private sector roles. Postdoctoral programs could more clearly draw upon literature related to the importance of mentorship in academic contexts and provide structured opportunities for faculty supervisors to develop the skills necessary to mentor postdocs for a variety of future career trajectories (see for example Johnson 2002, 2007).

The discordant alignment between the priorities of postdocs, the professional learning and development opportunities offered, and the realities of postdoc employment opportunities was apparent. As highlighted in our findings, there appears to be a unidirectional push toward research development priorities versus a shared understanding of postdoctoral scholars' priorities and the skill sets required to be successful across multiple career trajectories. Professional learning and development activities that specifically target postdocs needs may result in better uptake when they are perceived as useful (Welp et al., 2018). A fully integrated approach with structured intent may be beneficial. Based on participant dialog, there is a need to enhance attention to priorities, context, and relevance between postdocs priorities, the realities of career options, and the implementation of professional learning and development opportunities provided. Codevelopment of professional learning and development opportunities that includes postdocs and potential future employers, from planning stages through to integrated implementation (Bowen and Graham, 2013) may result in better uptake and perceived usefulness of professional learning and development opportunities. Approaching the planning, development, implementation, and evaluation of professional learning and development opportunities from this angle may enhance the quality and relevance of opportunities through active participation of postdocs (Van de Ven and Johnson, 2006).

It is also recognized that the perceived usefulness of the workshops may relate to the quality of the structure and facilitation of these opportunities. Professional learning research clearly indicates that these opportunities are best when: they provide opportunities for participants to actively construct their own knowledge; situate their learning in context, practice, and past experience; and, engage in social and collaborative learning (Webster-Wright, 2009). Our findings speak to the importance of ensuring that those who lead and design professional learning and development sessions are trained to ensure they provide meaningful learning experiences for postdoctoral scholars.

Continuous professional learning and development is significant for today's professional workforce (Friedman and Phillips, 2004; Webster-Wright, 2009), and may be especially important for postdocs. Professional learning and development should be related to current and future practice (Garet et al., 2001) yet many opportunities fail to meet participants authentic needs (Gravani, 2007). The findings of this study may be used to inform resource allocation and objectives of professional learning and development initiatives for postdoctoral scholars.

This study was undertaken at one university and may not be generalizable to other locations where the context may vary. Furthermore, participants self-selected to participate in the study. However, this study is strengthened by the inclusion of postdoctoral scholars from a range of disciplines. The concurrent mixed-methods design was useful in gathering data from the broader postdoc community while providing the depth of a qualitative study (Creswell, 2014; Tashakkori and Teddlie, 2010). Although we had a small sample size in terms of responses to the survey, we collected rich qualitative data that provided significant descriptions about postdocs perspectives about their professional learning and development. The inclusion of a variety of disciplines allowed us to explore the various perspectives of professional learning and development, however, comparison with postdoc from other schools across Canada and internationally would strengthen the research. More research is needed to accurately capture and document the current status and types of professional learning and development provided for postdocs across institutions. Further research should also study the effectiveness of diverse professional learning and development approaches and the impact these have on postdocs success in future careers.

Practice implications. The results of this research my be of use to several target audiences, including postdocs, postdoc supervisors, and those who are responsible for planning, implementing, and 
evaluating professional learning and development opportunities for postdocs. Postdocs may use these findings to guide them towards professional learning and development opportunities that have been perceived as beneficial by their postdoc peers. Postdoc supervisors may use these findings to co-develop professional learning and development plans with the postdocs they supervise and identify key opportunities for growth and development. For those who are responsible for planning, implementing and evaluating professional learning, and development opportunities for postdocs, these finding may be useful to refine and/or develop new opportunities tailored specifically to meet postdocs identified needs and preferences.

\section{Conclusion}

Postdocs require broad skills sets to ensure success after their postdoctoral tenure. However, professional learning and development of postdocs is multifaceted and a number of factors influence postdocs ability to engage in various professional learning and development opportunities, and institutions ability to provide useful opportunities. This study helps move the professional learning and development of postdocs agenda forward by describing postdocs perceptions of professional learning and development, and the usefulness of current strategies. The finding may be used by postsecondary institutions to inform the development of future professional learning and development strategies with the aim of meeting the needs of both postdocs and their future employers.

\section{Data availability}

The datasets generated during and/or analyzed during the current study are not publicly available due to the identifiable nature of the participants, but are available from the corresponding author on reasonable request.

Received: 19 January 2020; Accepted: 15 April 2020;

Published online: 13 May 2020

\section{References}

Åkerlind G (2005) Postdoctoral researchers: roles, functions and career prospects. High Educ Res Dev 24(1):21-40. https://doi.org/10.1080/0729436052000318550

Bowen, Graham (2013) Integrated knowledge translation. In: Straus S, Tetroe J, Graham I (eds) Knowledge translation in health care: moving from evidence to practice, 1st edn. Wiley, Oxford

Brownell SE, Tanner KD (2012) Barriers to faculty pedagogical change: lack of training, time, incentives, and tensions with professional identity? CBE-Life Sci Educ 11(4):339-346. https://doi.org/10.1187/cbe.12-09-0163

Clotfelter CT (2010) American universities in a global market. University of Chicago Press, Chicago

Creswell J (eds) (2014) Research design: qualitative, quantitative, and mixed methods approaches, 4th edn. Sage, Thousand Oaks

Edge J, Munro D (2015) Inside and outside the academy: valuing and preparing $\mathrm{PhDs}$ for careers. Available via https://www.conferenceboard.ca/elibrary/abstract. aspx?did=7564\&AspxAutoDetectCookieSupport=1. Accessed 14 April 2020

Friedman A, Phillips M (2004) Continuing professional development: developing a vision. J Educ Work 17(3):361-376. https://doi.org/10.1080/1363908042000267432

Fuhrmann CN, Halme DG, O'Sullivan PS, Lindstaedt B (2011) Improving graduate education to support a branching career pipeline: recommendations based on a survey of doctoral students in the basic biomedical sciences. CBE-Life Sci Educ 10(3):239-249. https://doi.org/10.1187/cbe.11-02-0013

Garet MS, Porter AC, Desimone L, Birman BF, Yoon KS (2001) What makes professional development effective? results from a national sample of teachers. Am Educ Res J 38(4):915-945. https://doi.org/10.3102/00028312038004915

Gravani MN (2007) Unveiling professional learning: shifting from the delivery of courses to an understanding of the processes. Teach Teach Educ 23 (5):688-704. https://doi.org/10.1016/j.tate.2006.03.011
Halpren ES (1983) Auditing naturalistic inquiries: the development and application of a model. Dissertation, Indiana University

Jadavji N, Adi M, Corkery T, Inoue J, Van Benthem K (2016) The 2016 Canadian National Postdoctoral Survey Report. Available via http://www.caps-acsp.ca/ wp-content/uploads/2016/11/2016_CAPS-ACSP-

National_Postdoc_Survey_Report.pdf. Accessed 14 April 2020

Johnson B (2002) The intentional mentor: strategies and guidelines for the practice of mentoring. Prof Psychol 33(1):88-96

Johnson B (2007) Transformational supervision: when supervisors mentor. Prof Psychol-Res Pr 38(3):259-267

Koch T (1994) Establishing rigour in qualitative research: the decision trail. J Adv Nurs 19(5):976-986. https://doi.org/10.1111/j.1365-2648.1994.tb01177.x

Lee YJ, Green JC (2007) The presictive validity of an ESL placement tests: a mixed methods approach. J Mixed Method Res 1:366-389

Lincoln Y, Guba EG (1985) Naturalistic inquiry. Sage, Newbury Park

McKenzie M (2007) Where are the scientists and engineers? Available via http:// www.statcan.gc.ca/pub/88f0006x/88f0006x2007002-eng.pdf. Accessed 14 April 2020

Miles M, Huberman A, Saldana J (2014) Qualitative data analysis: a methods sourcebook, 3rd edn. Sage, Los Angeles

Nerad M, Cerny J (1999) Postdoctoral patterns, career advancement, and problems. Science 285(5433):1533-1535

Nowell L, Norris J, White D, Moules N (2017) Thematic analysis: striving to meet the trustworthiness criteria. Int J Qual Meth 16:1-13. https://doi.org/10.1177/ 1609406917733847

Nowell L, Ovie G, Berenson C, Kenny N, Hayden KA (2018) Professional learning and development of postdoctoral scholars: a systematic review of the literature. Educ Res Int 2018:1-16. https://doi.org/10.1155/2018/5950739

Nowell L, Ovie G, Kenny N, Hayden KA, Jacobsen M (2020) Professional learning and development initiatives for postdoctoral scholars. Stud Grad Stud Postdoctoral Educ 11(1):35-55. https://doi.org/10.1108/SGPE-03-2019-0032

Onwuegbuzie AJ, Dickinson WB (2008) Mixed methods analysis and information visualization: graphical display for effective communication of research results. Qual Rep. 13:204-225

Pallant J (2013) A step by step guide to data analysis using IBM SPSS: SPSS survival manual, 5th edn. Open University Press, Berkshire

Rattray J, Jones MC (2007) Essential elements of questionnaire design and development. J Clin Nurs 16(2):234-243. https://doi.org/10.1111/j.13652702.2006.01573.x

Rybarczyk B, Lerea L, Lund PK, Whittington D, Dykstra L (2011) Postdoctoral training aligned with the academic professoriate. BioSci 9:699-705. https:// doi.org/10.1525/bio.2011.61.9.8

Tashakkori A, Teddlie C (2010) Sage handbook of mixed methods in social science and behavioral research, 2nd edn. Sage, Thousand Oaks

Tobin GA, Begley CM (2004) Methodological rigour within a qualitative framework. J Adv Nurs 48(4):388-396. https://doi.org/10.1111/j.13652648.2004.03207.x

Van de Ven AH, Johnson P (2006) Knowledge for science and practice. Acad Manag Rev 31(4):822-829

Webster-Wright A (2009) Reframing professional development through understanding authentic professional learning. Rev Educ Res 79(2):702-739. https://doi.org/10.3102/0034654308330970

Welp A, Johnson A, Nguyen H, Perry L (2018) The importance of reflecting on practice: how personal professional development activities affect perceived teamwork and performance. J Clin Nurs 27(21):3988-3999. https://doi.org/ $10.1111 /$ jocn. 14519

\section{Acknowledgements}

This work was partially funded by a University of Calgary Scholarship of Teaching and Learning Grant.

\section{Competing interests}

The authors declare no competing interests.

\section{Additional information}

Correspondence and requests for materials should be addressed to L.N.

Reprints and permission information is available at http://www.nature.com/reprints

Publisher's note Springer Nature remains neutral with regard to jurisdictional claims in published maps and institutional affiliations. 
(c) (i) Open Access This article is licensed under a Creative Commons Attribution 4.0 International License, which permits use, sharing, adaptation, distribution and reproduction in any medium or format, as long as you give appropriate credit to the original author(s) and the source, provide a link to the Creative Commons license, and indicate if changes were made. The images or other third party material in this article are included in the article's Creative Commons license, unless indicated otherwise in a credit line to the material. If material is not included in the article's Creative Commons license and your intended use is not permitted by statutory regulation or exceeds the permitted use, you will need to obtain permission directly from the copyright holder. To view a copy of this license, visit http://creativecommons.org/ licenses/by/4.0/.

(C) The Author(s) 2020 